\title{
Palaeomagnetism of the Bayan Gol Formation, western Mongolia
}

\author{
D. A. EVANS*, A. YU. ZHURAVLEV †, C. J. BUDNEY \& J. L. KIRSCHVINK* \\ * Division of Geological and Planetary Sciences, California Institute of Technology, Pasadena, CA 91125, USA \\ $\div$ Palaeontological Institute, Russian Academy of Sciences, 117647 Moscow, Russia \\ $\ddagger$ Department of Geology and Geophysics, University of Hawaii, 2525 Correa Rd., Honolulu, HI 96822, USA
}

(Received 17 November 1994; revised version received 27 February 1996; accepted 28 February 1996)

\begin{abstract}
Oriented samples of the Lower Cambrian Bayan Gol Formation from Salaany Gol, Mongolia, were collected at roughly $5 \mathrm{~m}$ stratigraphic intervals for palaeomagnetic analysis. Progressive alternatingfield and thermal demagnetization isolated two magnetic components: a present-field overprint, typically removed by $10 \mathrm{mT}$ fields and $\sim 200^{\circ} \mathrm{C}$ heating; and a high-coercivity, high-unblocking-temperature $\left(550-600^{\circ} \mathrm{C}\right)$, predominantly single-polarity component that was imparted to the rocks prior to early or middle Palaeozoic deformation. Single-polarity magnetization at Salaany Gol contrasts with results from Lower Cambrian rocks on the Siberian platform, previously considered correlative with the Bayan Gol Formation, which show a prominent change in polarity bias near the top of the Tommotian Stage. Two hypotheses can explain this discrepancy. First, the entire Bayan Gol Formation may correlate with the predominantly reversely polarized, lower half of the Tommotian Stage in Siberia. This model is consistent with plausible interpretations of $\delta^{13} \mathrm{C}$ profiles for the Zavkhan basin and the Siberian platform. Alternatively, the characteristic magnetic direction from our samples may be a pre-fold overprint. If post-accretionary, then comparison with Siberian palaeomagnetic results suggest a Silurian-Devonian remagnetization age, and existing bioand chemostratigraphic correlations provide the most reliable spatial and temporal links between the Zavkhan basin and the Siberian platform. If the observed magnetic directions are primary or an immediate overprint then they may be used to constrain the early Cambrian palaeogeography of the Zavkhan basin and the Palaeo-Pacific Ocean. Mean inclination of $62 \pm 4^{\circ}$ corresponds to a palaeolatitude of $44 \pm 5^{\circ}$, several thousand kilometres from the equatorial Siberian craton.
\end{abstract}

\section{Introduction}

The Zavkhan basin contains a $\sim 1-2-\mathrm{km}$-thick Neoproterozoic-Cambrian sedimentary sequence deposited on Riphean volcanic rocks (Voronin et al. 1982). The Bayan Gol Formation, primarily siliciclastic with calcareous interbeds, contains small shelly fossils that are thought to correlate with Nemakit-Daldynian to lower Atdabanian (Voronin et al. 1982) or NemakitDaldynian to earliest Tommotian (Brasier et al. 1996, this issue) biozones in Siberia. The sequence is well exposed at Salaany Gol, in the Khasagt-Khayr Khan Mountains $\sim 50 \mathrm{~km}$ northwest of Altay (Fig. 1).

The thickness and excellent fossil content of the Salaany Gol locality make it potentially useful for magnetostratigraphic comparisons with other Vendian-Cambrian sections throughout the world. Magnetostratigraphy, in conjunction with carbon isotope stratigraphy, has helped refine palaeontological correlations among basins in Siberia, Morocco, and China (Kirschvink et al. 1991). This study is the first palaeomagnetic analysis of Neoproterozoic-Cambrian rocks in the Zavkhan basin.

\section{Sampling and analysis}

More than 200 oriented core and block samples were collected throughout the Bayan Gol Formation, from three adjacent profiles with slightly overlapping stratigraphy
(Figs 1,2). The lowest sample, near the base of the Bayan Gol Formation, is coincident with the base of the Tiksitheca licis-Maikhanella multa Zone (here and below, sensu Voronin et al. 1982; for modified versions of this scheme see Brasier et al. 1996, this issue). Aside from a $120 \mathrm{~m}$ interval of poor exposure near the top of this zone, sample spacing is on the order of $5 \mathrm{~m}$ throughout the higher zones Ilsanella compressa, Anabarella plana, Tannuella gracilis and Stenothecoides. Two of the sample profiles (A and B, Fig. 1) cross moderately dipping strata, whereas the third $(C)$ transects subvertical layers. The $\sim 40^{\circ}$ difference in bedding dip permits a fold test, whereby the age of magnetization can be compared with the age of folding.

Samples were oriented in the field by both magnetic and solar compasses. Once collected, the 2.5 -cm-diameter cylindrical cores were trimmed to $2.3 \mathrm{~cm}$ length. From the block samples, cores were drilled, oriented, and trimmed in the laboratory. Samples were measured in an SCT-2 $\mathrm{G}^{\circledR}$ superconducting moment magnetometer inside a magnetically shielded room. Specimens were subjected to $2.5 \mathrm{mT}$ steps of alternating-field (AF) demagnetization up to 10 $\mathrm{mT}$, followed by thermal demagnetization (heating and cooling in zero field) at $50^{\circ} \mathrm{C}$ steps from $200^{\circ} \mathrm{C}$ to $650^{\circ} \mathrm{C}$, or until sample intensity dropped to the instrument noise level. Measurements were made after each partial demagnetization step. Magnetic components were separated by linear principal-component-analysis (Kirschvink, 1980). 

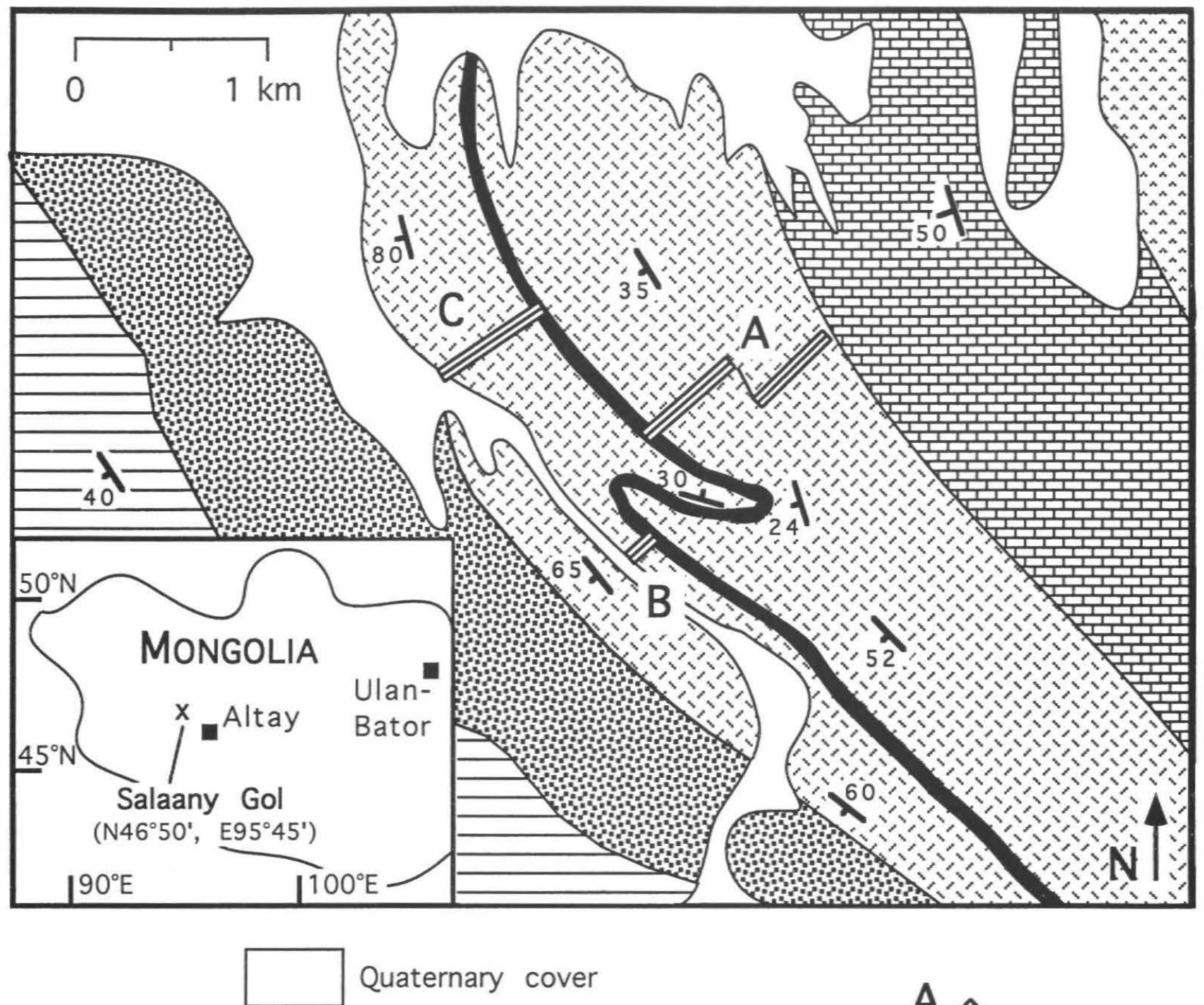

\section{Cambrian}

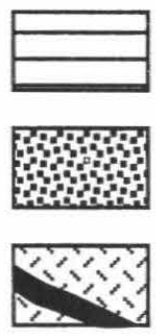

Khayrkhan Fm.

Salaany Gol Fm.

Bayan Gol Fm.

with marker horizon ' $\Pi$ '

\section{Vendian}

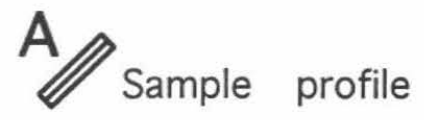

Figure 1. Geological map of Salaany Gol, after Voronin et al. (1982, p. 8).

\section{2.a. Sample data}

Examples of sample demagnetization paths are shown in Figure 3. Natural remanent magnetization (NRM) moments varied from $10^{-9}$ to $10^{-6} \mathrm{Am}^{2}$ (or $10^{-6}$ to $10^{-3} \mathrm{emu}$ ), with typical values of $10^{-8} \mathrm{Am}^{2}\left(10^{-5} \mathrm{emu}\right)$. Almost all of the samples yielded coherent demagnetization paths with distinct components. NRM vectors generally comprise two components. The first of these to be removed, primarily in the alternating field steps or the $200^{\circ} \mathrm{C}$ thermal steps, is aligned with the present geomagnetic field. The (1) low coercivity and (2) low unblocking temperature of this com- ponent suggest that it is held (1) partly by multidomain magnetite, and (2) partly by goethite. The second magnetic component is generally removed between temperatures of $350^{\circ} \mathrm{C}$ and $550-600^{\circ} \mathrm{C}$. The unblocking temperature of this component suggests that magnetite is the dominant remanence carrier. For each sample, we call the last distinguishable component to be removed the characteristic remanent magnetization (ChRM). In many samples the demagnetization paths do not decay to the origin. Although this may suggest an additional component for each sample, least-squares-plane analysis demonstrates that such com- 


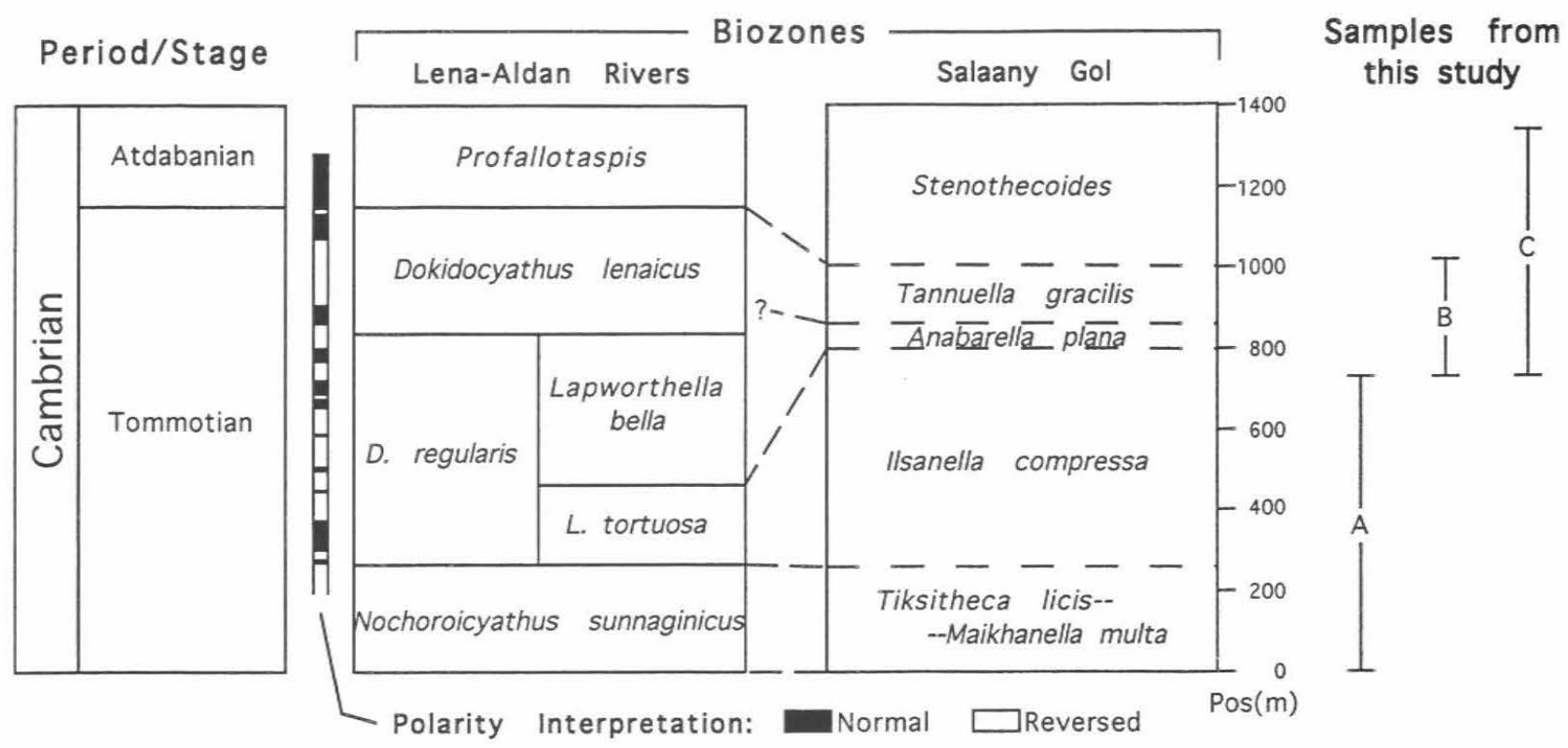

Figure 2. Biostratigraphic correlation between Mongolia and Siberia, after Voronin et al. (1982, p. 13). Magnetic polarity interpretation from Siberian reference sections along the Lena River, according to Kirschvink et al. (1991). Stratigraphic thicknesses of Mongolian and Siberian sections are not to scale.

ponents are randomly oriented throughout the suites of samples (Fig. 4c). Thus the chosen ChRM is the most stable and geologically meaningful component for each sample. All subsequent evaluation of the data concerns ChRMs only.

\section{Interpretation of magnetic directions}

Twenty-one specimens from a total of 220 were thoroughly remagnetized by the present Earth field; because this direction differs substantially from the other population of ChRM directions, these samples are easily identifiable and will be ignored in the following discussion. ChRM directions from all remaining samples are shown in Figure 4, in tilt-corrected coordinates. Most show a steep, negatively inclined (upward), north-northwest direction in restored coordinates. When viewed in present (in situ) coordinates, however, ChRMs from the moderately dipping (profiles A and B) rocks cluster in a significantly distinct direction from ChRMs of the subvertical (profile C) samples (Fig. 5). Thus the component qualitatively passes a fold test, indicating acquisition prior to deformation. Bootstrap statistical analysis (McFadden, 1990) confirms this result (Table 1): parallelism between the two groups in present coordinates can be rejected with $>99.9 \%$ confidence, whereas the same hypothesis for the tilt-corrected data can only be rejected with $<50 \%$ confidence. In this case, note that the statistics only reinforce visually obvious results.

Tight folding at Salaany Gol probably occurred during Palaeozoic accretions of the Altaid orogenic collage onto the Siberian platform (Mossakovsky et al. 1992, 1994; Şengör, Natal'in \& Burtman, 1993). The tight, north- west-southeast fold across which our samples were collected may be cogenetic with a thrust in the eastern part of the range, that is truncated by Palaeozoic granite (fig. 3 of Khomentovksy \& Gibsher, 1996, this issue). This granite has been dated as Devonian (Khasin, Borzakovskiy \& Zonenshayn, 1973), consistent with subsequent recognition of a regional Devonian magmatic episode (Yashina, Matrenitskiy \& Garam, 1979). Therefore, our pre-fold characteristic magnetization is pre-Devonian if our structural correlations and existing geochronological data are correct.

Although most specimen ChRM directions lie in the steep negative north-northwest octant of the unit sphere, several outliers demand attention. Using the discordancy test outlined by Fisher, Lewis \& Embleton (1987, p. 126) with a $10 \%$ probability cutoff, 25 samples are excluded from the modal population. By this filter, 174 samples within $\sim 84^{\circ}$ arc length of the mean direction are included in the modal subset. Spurious ChRMs may be explained by unusual occurrences such as close proximity to lightning strikes, local chemical remagnetization, or acquisition in the transitional geomagnetic field during a reversal. Because our samples show predominantly single polarity, however, the latter explanation is less likely than the others. For some outlying samples, discrepancy between magnetic and solar compass measurements on the outcrop suggests they have been remagnetized by lightning strikes.

Extremely outlying samples may record opposite geomagnetic polarity to that of the mode. Consistency of each magnetic polarity among stratigraphically adjacent samples is an important test of the reversal hypothesis (e.g. Kirschvink, 1978). Nineteen samples lie within $84^{\circ}$ arc 


\section{Sample A46}

Sample A71
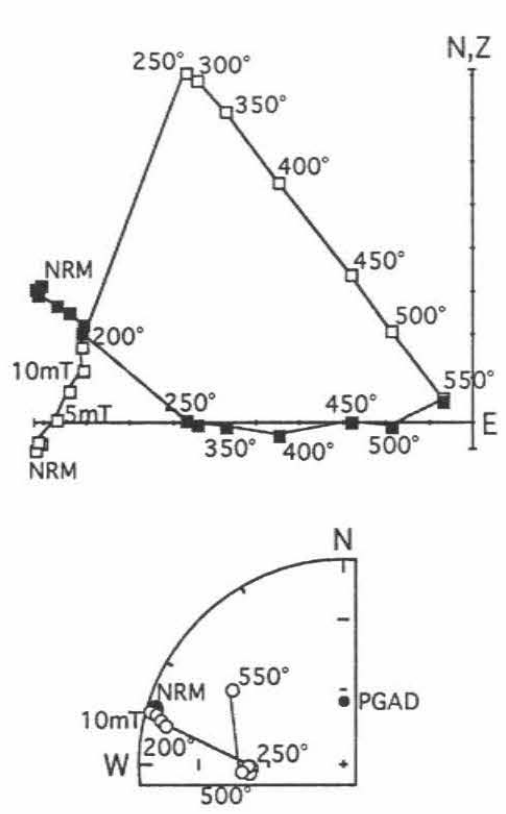

\section{Sample B14}

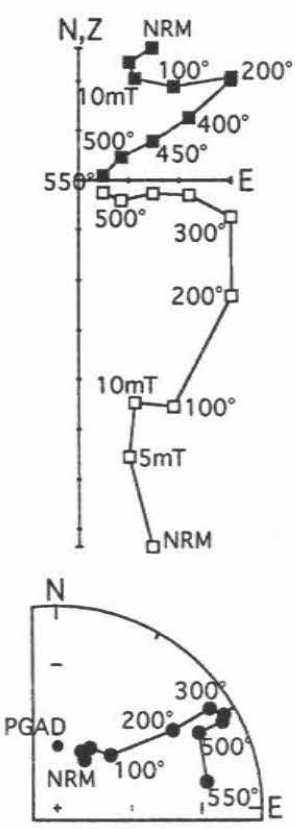

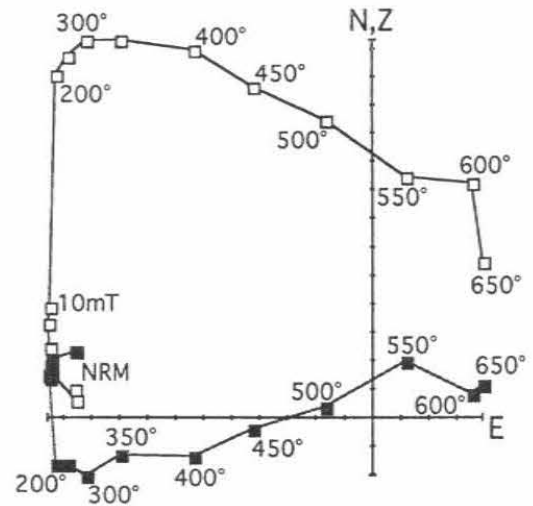

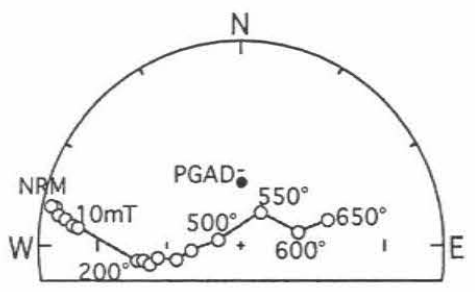

Sample C85

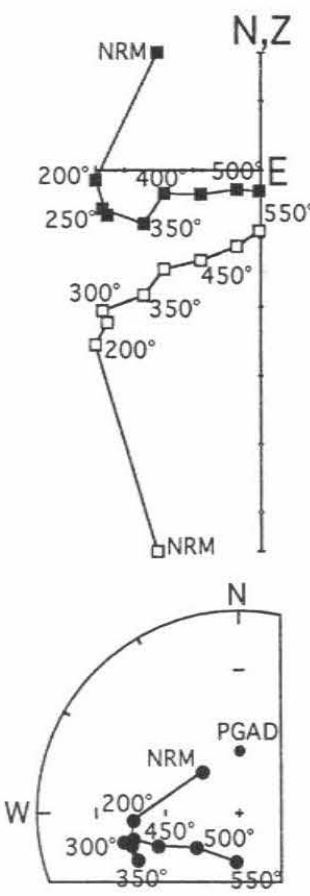

Sample A85
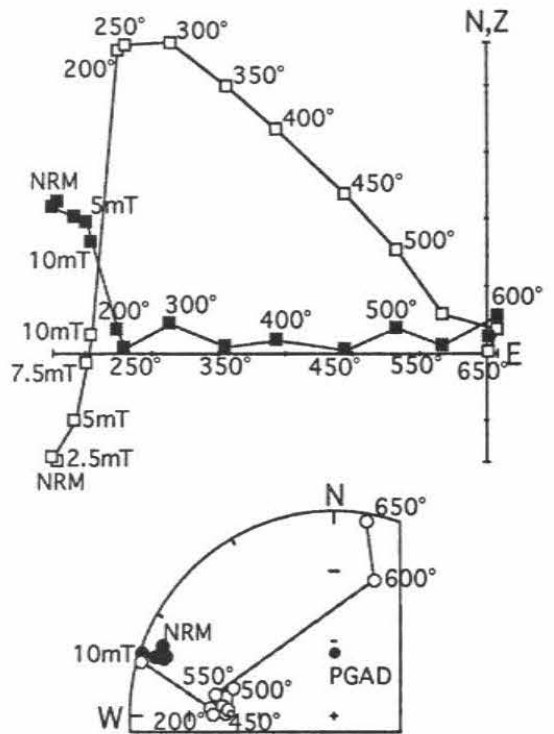
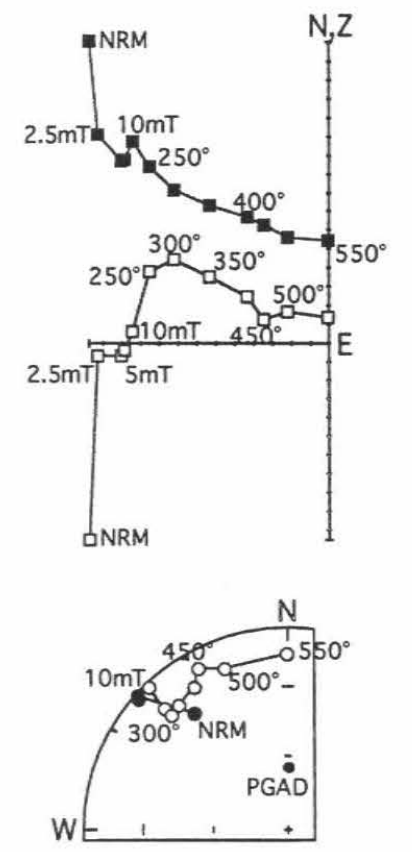

Figure 3. Representative sample demagnetization paths, in present coordinates. For each sample, upper diagram presents superimposed orthogonal projections of sample moment, onto the east-west vertical (open boxes) and horizontal (filled boxes) planes. Temperature steps in ${ }^{\circ} \mathrm{C}$. NRM = natural remanent magnetization. Tick marks at $10^{-9} \mathrm{Am}^{2}\left(10^{-6} \mathrm{emu}\right)$. Lower diagrams show equal-area projections of the same paths, symbols as in Figure 4. PGAD = present geocentric axial dipole direction for Salaany Gol.

length of the antipole to the mean direction and may be of opposite polarity (Figs 4,6 ). Of these, one (at $258 \mathrm{~m}$ ) is adjacent to the only wide sample gap, so opposite polarity may continue into that interval. Two are immediately adjacent to each other $(\sim 758 \mathrm{~m})$. Others occur in stratigraphic isolation, although several clusters occur within relative 

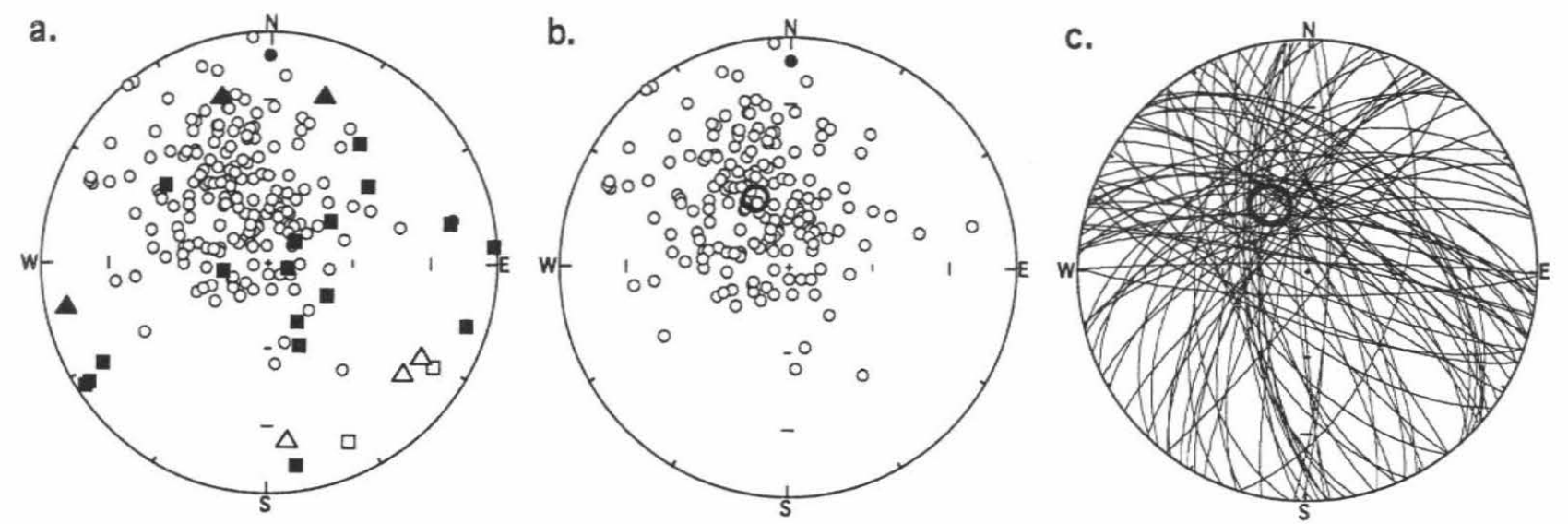

Figure 4. Equal-area projections of ChRM directions in tilt-corrected coordinates. Solid (open) symbols represent vectors projected from the lower (upper) hemisphere of the unit sphere. (a) All non-present-field ChRM directions from Salaany Gol. Squares depict samples with opposite polarity to the modal population. Triangles depict outliers from either polarity. (b) Non-present-field ChRM directions as in (a), but excluding all outliers from the modal population. Dark ellipse is the projection of the $95 \%$ confidence cone around the Fisher mean. (c) Least-squares planes from profile C, projected onto the upper hemisphere. Each plane contains a sample's ChRM vector and the origin. Dark ellipse is the projection of the $95 \%$ confidence cone around the best-fit common vector among the planes.

Table 1. Fold test of modal ChRM directions

\begin{tabular}{|c|c|c|c|c|c|c|c|c|c|c|c|}
\hline \multirow[b]{2}{*}{ Coordinates } & \multicolumn{4}{|c|}{ Sample profiles A,B } & \multicolumn{4}{|c|}{ Sample profile C } & \multicolumn{3}{|c|}{ Test results } \\
\hline & D & I & $\mathrm{N}$ & $\mathrm{k}$ & D & I & $\mathrm{N}$ & k & $\mathrm{V}_{0}$ & $\mathrm{n}_{(\%)}$ & $\mathrm{V}_{\text {(Conf } \%)}$ \\
\hline Present & 275.7 & -38.7 & 84 & 6.0 & 280.6 & 5.0 & 90 & 9.3 & 156 & $\begin{array}{l}99.9 \\
99\end{array}$ & $\begin{array}{l}41 \\
25\end{array}$ \\
\hline Restored & 327.4 & -64.2 & 84 & 5.7 & 337.3 & -60.5 & 90 & 9.5 & 2.8 & $\begin{array}{l}90 \\
50 \\
40\end{array}$ & $\begin{array}{c}12 \\
3.3 \\
2.4\end{array}$ \\
\hline
\end{tabular}

Bootstrap test from McFadden (1990). For each coordinate system, the two subset distributions are tested for parallelism. $\mathrm{V}_{0}$ indicates the degree of seperation between the groups. $\mathrm{V}_{\left(\mathrm{n} \xi_{\mathrm{f}}\right)}$ gives the nth-percentile seperation between two groups randomly selected from a common Fisher distribution. If $\mathrm{V}_{0}$ exceeds $\mathrm{V}_{(\mathrm{n} \%)}$, then parallelism can be rejected with ( $\mathrm{n} \%$ ) confidence. Bootstraps were run with 3000 iterations.

Abbreviations: D, I = Fisher mean declination and inclination, $\mathrm{k}=$ Fisher precision parameter, $\mathrm{N}=$ number of samples, $\mathrm{n}=$ confidence percentile.

proximity (2-8 m; 589-622 m; 755-766 m; 1095-1109 m). These concentrations may represent geomagnetic polarity bias, but the general stratigraphic sporadicity suggests that antipolar samples may be in fact members of a superimposed uniform population. Indeed, treating these singlehemispherically distributed outliers as axial data (Fisher, Lewis \& Embleton, 1987, p. 160) shows that we cannot reject uniformity with $>90 \%$ confidence.

Because our evidence for geomagnetic polarity reversals is not conclusive, the following discussion entertains not only that possibility, but also the chance that the antipodal ChRMs result from some other sources of error and lie coincidentally opposite the modal ChRM directions.

\section{3.a. Bimodal primary magnetization hypothesis}

If the consistent magnetization at Salaany Gol is primary and bipolar, then comparison with magnetostratigraphy of Siberia brings a surprise: there, previous work has shown a major magnetic polarity shift from mainly reversed to predominantly normal bias in the uppermost Tommotian Stage (Kirschvink et al. 1991; Fig. 2). The Mongolian data presented here are predominantly single polarity, at odds with the previous correlation by Voronin et al. (1982). Small polarity zones in the Siberian section are common enough to allow ready correlation of our widely scattered opposite-polarity intervals in a variety of non-unique alternatives, but these must be validated by bio- and chemostratigraphic data.

Figure 7 presents one such model. Brasier et al. (1996, this issue) describe several cycles of $\delta^{13} \mathrm{C}$ within the Bayan Gol Formation, which they claim are removed by the subTommotian unconformity on the southern Siberian platform. Their correlation thus bears no prediction for magnetostratigraphy at Salaany Gol; nonetheless, it demands a rather substantial revision to the original biostratigraphic study (Voronin et al. 1982). On the other hand, the palaeontological correlation by Voronin et al. (1982) is fairly consistent with the $\delta^{13} \mathrm{C}$ data from the two regions (Siberian cycle IV coeval with Mongolian cycle F), but the magnetostratigraphic records are inconsistent with this interpretation. Therefore, we present a compromise that generally satisfies all three stratigraphies, whereby the entire sampled part of the Bayan Gol Formation spans only early Tommotian time, from the $N$. sunnaginicus through the middle $L$. bella zones. In our correlation, Mongolian 


\section{Profiles $A, B$}
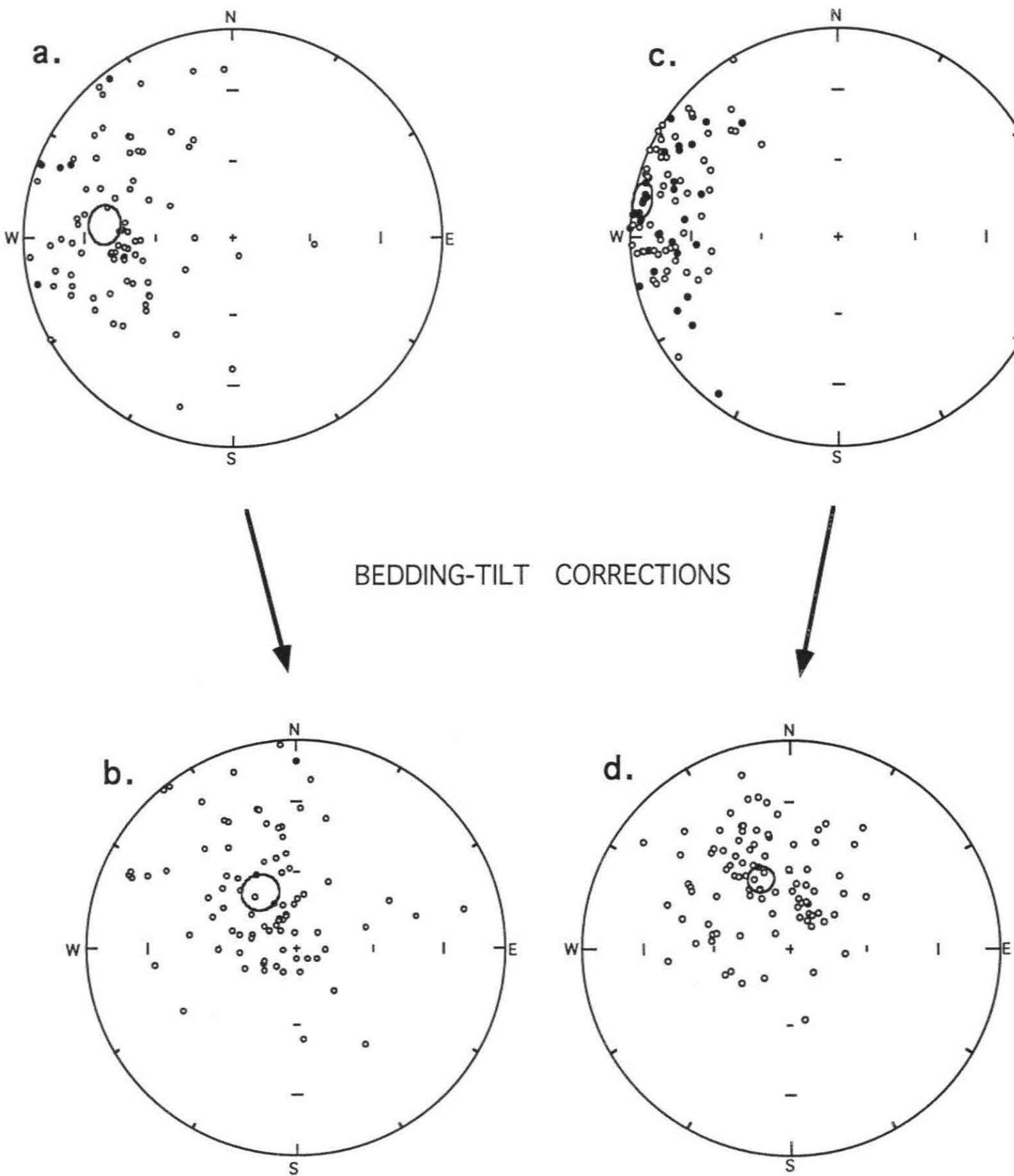

Figure 5. Graphical illustration of the Salaany Gol fold test. Subset of ChRM directions excludes present-field values and distant outliers. Equal-area projections with symbols as in Figure 4. For statistical data, see Table 1. (a) Samples from profiles A and B in present coordinates. (b) Profile A and B samples in tilt-corrected coordinates. (c) Samples from profile C in present coordinates. (d) Profile C samples in tilt-corrected coordinates. Note close alignment of the two subset means after tilt correction (panels (b) and (d)).

cycles $\mathrm{E}$ and $\mathrm{F}$ (Brasier et al. 1996, this issue) correspond to Siberian cycles II and III, respectively.

Primary magnetic remanence implies a depositional palaeolatitude of $44 \pm 6^{\circ} \mathrm{N}$ (Table 2, first row). By compar-
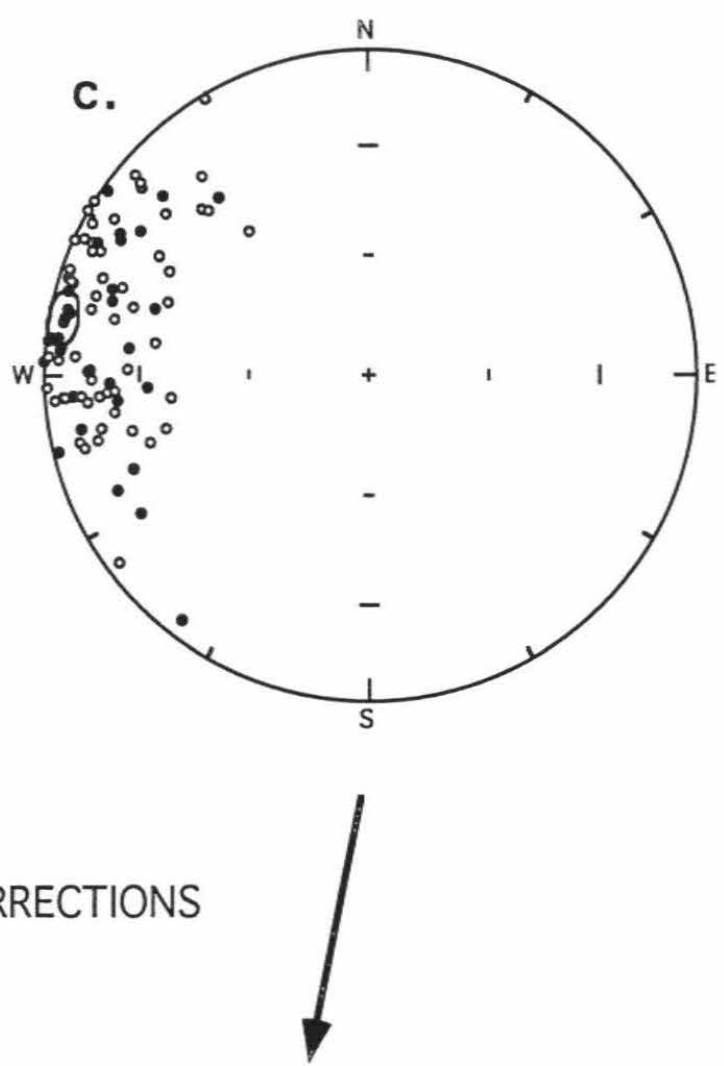
Table 2. Fisher statistics of ChRM directions excluding present-field and distant outliers

\begin{tabular}{|c|c|c|c|c|c|c|c|c|c|c|c|c|c|c|c|}
\hline \multirow[b]{2}{*}{ Subset } & \multirow[b]{2}{*}{$\mathrm{N}$} & \multicolumn{4}{|c|}{ Mean direction } & \multicolumn{2}{|c|}{ Palaeomagnetic pole* } & \multicolumn{8}{|c|}{ Reliability } \\
\hline & & $\mathrm{D}\left({ }^{2}\right)$ & $I\left({ }^{\circ}\right)$ & k & $a_{95}$ & Lat. $\left({ }^{\circ} \mathrm{N}\right)$ & Long. $\left({ }^{\circ} \mathrm{E}\right)$ & 1 & 2 & 3 & 4 & 5 & 6 & 7 & Q \\
\hline $\begin{array}{l}\text { Including oppositely } \\
\text { directed ChRMs }{ }^{\dagger}\end{array}$ & 193 & 331.9 & -62.6 & 5.8 & 4.6 & 4.0 & 115.6 & 1 & 0 & 1 & 1 & 0 & 1 & 0 & 4 \\
\hline $\begin{array}{l}\text { Excluding oppositly } \\
\text { directed ChRMs }\end{array}$ & 174 & 333.1 & -62.3 & 7.1 & 4.3 & 3.5 & 114.9 & 1 & 0 & 1 & 1 & 0 & 0 & 0 & 3 \\
\hline
\end{tabular}

Abbreviations as in Table 1. Reliability criteria from Van de Voo (1990): (1) Age of rock well known, (2) N>24, $k \geq 10$, and $a_{05} \leq 16^{\circ}$, (3) Demagnetization and vector subtraction, (4) Field tests, (5) Tectonic coherence with craton, (6) Reversals, and (7) No resemblance to younger APW path. $Q=$ sum of satisfied criteria $1-7$.

* assuming reversed geomagnetic polarity

$\doteqdot$ reflected through origin

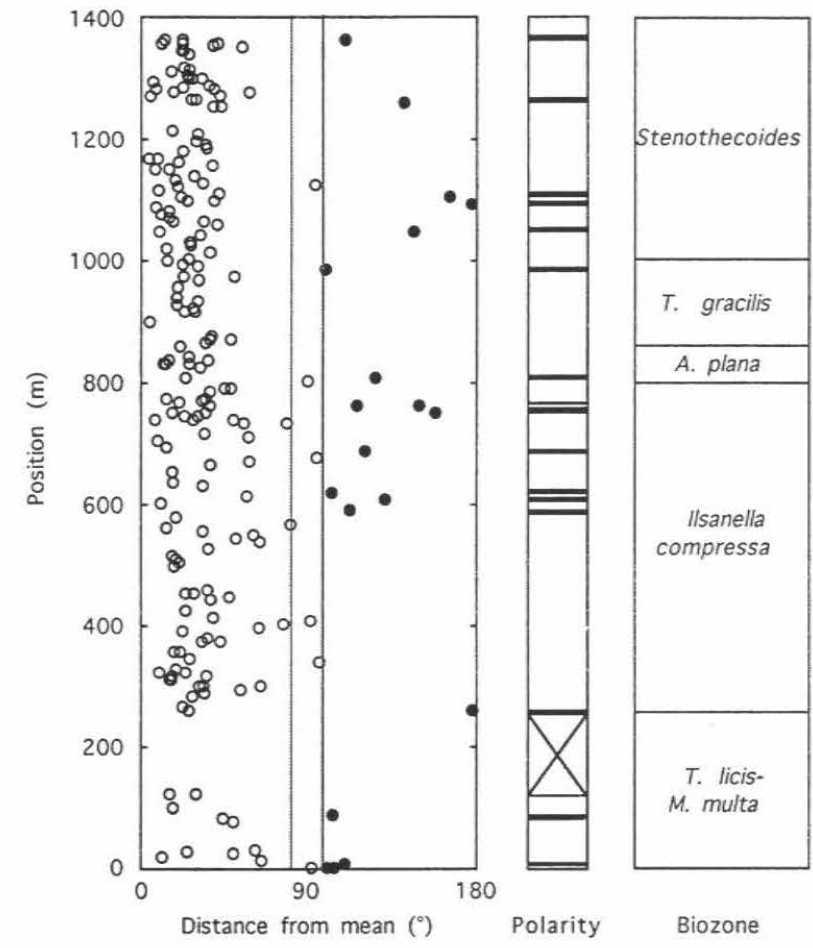

Figure 6. Stratigraphic variation in tilt-corrected ChRM directions, with geomagnetic polarity interpretations. Polarity symbols as in Figure 2. Arbitrary reversed polarity assigned to majority of samples. Filled circles correspond to samples denoted by squares in Figure 4 .

tudes in Early Cambrian time. Whereas our results reconstruct Mongolia to higher latitudes, thousands of kilometres between a craton and its adjacent back-arc basin is not unreasonable, given, for example, the present width of the Philippine Sea. The palaeotectonic model developed by Mossakovsky et al. (1992, 1994) suggests a 'PalaeoPacific' ocean between the Siberian craton and East Gondwanaland, to which Mongolian terranes primarily belonged. These terranes were rifted from East Gondwanaland, transported, and subsequently accreted to the Siberian craton during Vendian and early Palaeozoic time. Provinciality of Early Cambrian fauna from the Zavkhan basin provides a clue to palaeogeography. The compilation of data from Voronin et al. (1982); Voronova et al. (1986); Korobov (1989); Wood, Zhuravlev \&
Chimed Tseren (1993); Esakova \& Zhegallo (1996); and Ushatinskaya (1995), shows a distinct trend from Nemakit-Daldynian to Tommotian fauna of affinity with the Yangtze platform, and latest Atdabanian to earliest Botomian fauna of Siberian affinity (A. Zhuravlev, unpub. compilation), supporting the model by Mossakovsky et al. (1992, 1994). An alternative model, placing the Tuva-Mongol region, including rocks of the Zavkhan basin, adjacent to Siberia during Vendian-Cambrian time (Şengör, Natal'in \& Burtman, 1993), is inconsistent with this palaeontological compilation.

The Yangtze craton (South China block) was reconstructed to $\sim 5^{\circ}$ latitude by palaeomagnetic results from the Precambrian-Cambrian boundary section at Meishucun (Wu, Van der Voo \& Liang, 1988/9), but subsequent workers suggested a $\sim 40^{\circ} \mathrm{S}$ latitude for Sinian-Cambrian placement of South China (Wang, Van der Voo \& Wang, 1994). Unfortunately, the palaeopole derived in the latter study, which lacks any field stability tests, is similar to an Ordovician pole from South China (Fang, Van der Voo \& Liang, 1990) and may be a remagnetization of that age. Clearly, the Eocambrian drift history of the Yangtze craton needs to be better understood in order to assess our Mongolian palaeomagnetic result in context of the tectonic models by Mossakovsky et al. $(1992,1994)$.

\section{3.b. Coincidental antipolarity, remagnetization hypothesis}

Two variations of this conjecture are that magnetization may be either primary or secondary, but in either case it was acquired in a period of single geomagnetic polarity. ChRMs that are directed opposite to the mean direction are due to purely coincidental scatter or error. Final statistical treatment of the data excludes these along with the other widely aberrant directions (Table 2, second row). Fisher analysis gives a palaeomagnetic pole of $4^{\circ} \mathrm{N}, 115^{\circ} \mathrm{E}$, corresponding to a palaeolatitude of $43 \pm 5^{\circ} \mathrm{N}$ given a reversed field polarity during remanence acquisition.

A single-polarity, primary magnetization is less likely than one of dual polarity, for this requires that all of the normally magnetized Siberian intervals must be excluded from the stratigraphic record at Salaany Gol. More likely, single polarity would be due to a magnetic overprint. whereby no stratigraphic correlations with other Vendian- 
Lena River, Siberia

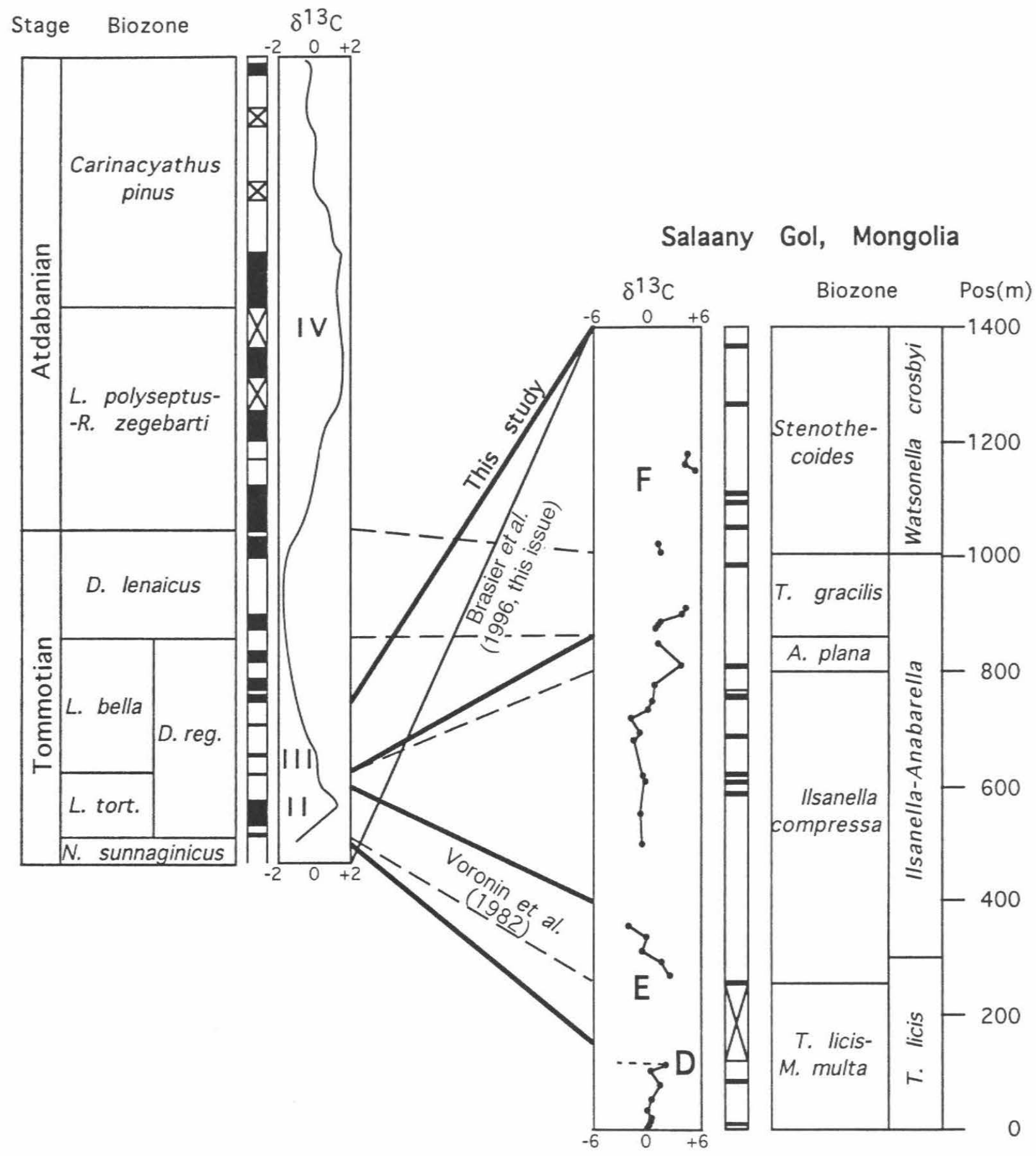

Figure 7. Various correlations of the Salaany Gol sequence with the Vendian-Cambrian of Siberia. Integrated magnetic polarity interpretation (symbols as in Fig. 2) and carbon-isotope data for Siberia, from Kirschvink et al. (1991). Carbon-isotope data and named cycles for Salaany Gol from Brasier et al. (1996, this issue); where dashed, from the Bayan Gol locality. Our preferred correlation, based on the assumption of primary detrital remanence with meaningful antipolar directions, is shown by the dark solid lines.

Cambrian reference sections are permitted. The wide scatter of our ChRMs implies averaging of geomagnetic secular variation, suggesting a stable but heterogeneous chemical remagnetization. Well-defined, linear ChRM components (Fig. 3 ) indicate that the randomly directed component remaining in many samples after $600{ }^{\circ} \mathrm{C}$, does not contribute to the scatter of ChRMs.

Because rocks of the Zavkhan basin are thought to have accreted to the Siberian craton during early Palaeozoic time (Mossakovsky et al. 1992, 1994) and lie 


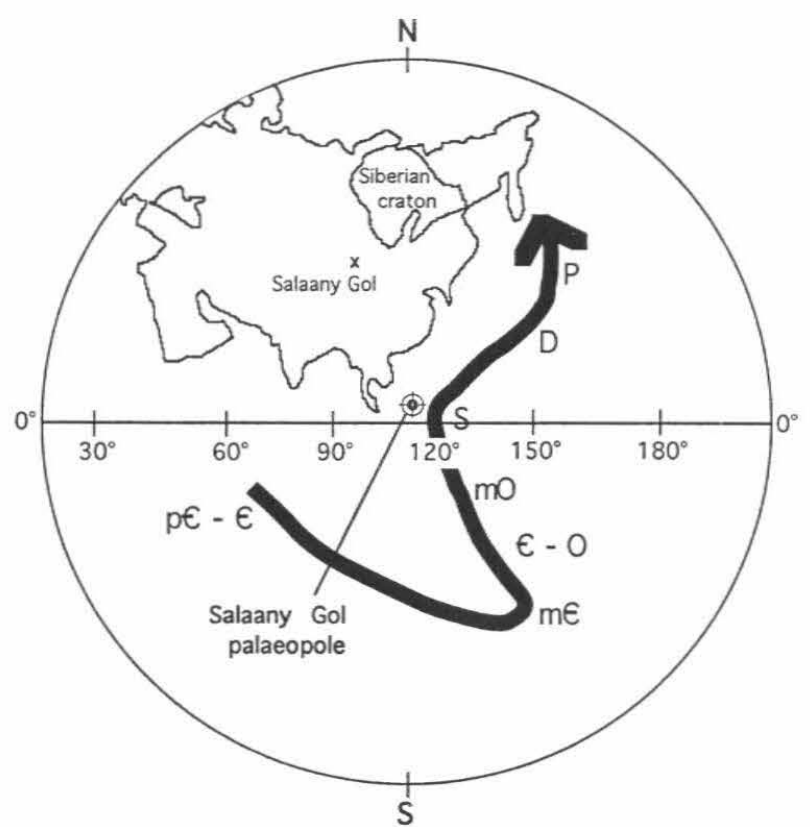

Figure 8. Relation between palaeomagnetic pole computed from this study to the Palaeozoic apparent polar wander path for the Siberian craton, compiled by Van der Voo (1993, p. 100), except for the Middle Cambrian position according to Khramov (1982, p. 302) and the Precambrian-Cambrian boundary pole from Kirschvink et al. (1991). Abbreviations: $\mathrm{p} €-\epsilon=$ Precambrian-Cambrian boundary, $\mathrm{mE}=$ Middle Cambrian, $\mathrm{\epsilon}-\mathrm{O}=$ Cambrian - Ordovician boundary, $\mathrm{mO}=$ Middle Ordovician, $\mathrm{S}=$ Silurian, $\mathrm{D}=$ Devonian, $\mathrm{P}=$ Permian.

north of the projected trace of the Mongol-Okhotsk suture (Gorzhevskiy \& Shabalovskiy, 1972), west Mongolian and Siberian apparent polar wander (APW) paths should be coincident from that time to the present, unless post-accretionary vertical axis rotation occurred between the two blocks. Thus, the Salaany Gol magnetic result should conform with Phanerozoic directions from Siberia, unless our magnetization was attained prior to accretion.

The mean pole position lies nearest to the Silurian portion of Siberia's APW path, although $\sim 60^{\circ}$ of postPalaeozoic clockwise rotation of the Khasagt-Khayr Khan Mountain (KKM) region, relative to Siberia, could have brought Devonian overprints to the observed palaeopole location (Fig. 8). This is in the opposite sense from Permian to Cretaceous anticlockwise rotations of the Tarim block relative to Siberia ( $\mathrm{Li}, 1990$; Van der Voo, 1993, p. 207); if the Salaany Gol magnetization is postSilurian, then subsequent rotations of the KKM region probably occurred independently from Tarim. PreJurassic palaeomagnetic results from eastern Mongolia (Pruner, 1992), across the Mongol-Okhotsk suture, are not applicable to the Zavkhan region.

Alternatively, remagnetization could have occurred prior to Altaid accretion of the Zavkhan basin onto the Siberian craton, possibly during early diagenesis, in which case discrepancies between Siberia's Cambrian APW path and our computed pole would be due to wide separation between the Siberian craton and the Zavkhan basin. In this case similarity between our pole and the middle Palaeozoic Siberian APW path is coincidental. Palaeogeographic implications are similar to those discussed in Section 3.a. Rapid closure of Palaeo-Pacifica, such that by latest Atdabanian time the Zavkhan basin had entered the Siberian faunal province, was followed by Cambrian-Ordovician accretion of the Zavkhan basin to Siberia during the Salairian orogeny (Mossakovsky et al. 1994). If the folding at Salaany Gol occurred during this accretion, then our positive fold test justifies these well constrained Cambrian palaeogeographic comparisons with the Siberian platform.

\section{Tests and summary}

The above arguments follow the implications of two alternative hypotheses to explain our palaeomagnetic results from Salaany Gol. These possibilities are testable by further palaeomagnetic and stratigraphic work. Magnetic conglomerate tests of volcanic clasts in the lower Tsagaan Oloom diamictites (Lindsay et al. 1996, this issue) could demonstrate primary remanence of the underlying Dzabkhan Formation and thus low probabilities of regional chemical or thermal remagnetization, or they could demonstrate regional magnetic overprinting. At present sample spacing of $\sim 5 \mathrm{~m}$, the Salaany Gol palaeomagnetic transect may pass over many short-lived magnetic polarity zones; future palaeomagnetic studies of the Bayan Gol and adjacent formations, at $<1 \mathrm{~m}$ sample spacing in several overlapping stratigraphic sections, should also help test whether our oppositely directed samples truly indicate geomagnetic reversals.

In summary, if the palaeomagnetism recorded at Salaany Gol is primary, then we can interpret not only Cambrian palaeogeography but also magnetostratigraphic comparisons with the Early Cambrian of Siberia. In that case the simplest model that is consistent with the magnetic and carbon-isotope stratigraphy is one whereby the sampled part of the Bayan Gol Formation is equivalent to the lower part of the Tommotian Stage. If the magnetization is an overprint, then it was probably acquired either (1) prior to accretion of the Zavkhan basin with the Siberian craton, implying wide separation between the two regions, or (2) following accretion, during Silurian-Devonian time. In any case the magnetization was acquired at about $44^{\circ}$ latitude.

Acknowledgements. We thank M. D. Brasier, J. Holt, J. Lindsay, R. Van der Voo and B. Wernicke for helpful suggestions. Sample analysis was supported by National Science Foundation Grants EAR-8721391 and PYI-8351370. Participation by D. Evans was supported by an NSF Graduate Research Fellowship. A. Zhuravlev's field work in 1982 was supported by a joint Soviet-Mongolian palaeontological expedition and by the Palaeontological Institute, Russian Academy of Sciences; his current effort is supported by the Russian Foundation for Fundamental Research, project no. 96-0564224. This work is a contribution to International Geological Correlation Program Project 320. California Institute of 
Technology Division of Geological and Planetary Sciences Contribution 5471

\section{References}

Brasier, M. D., Shields, G., Kuleshov, V. \& Zhegallo, E. 1996. Integrated chemo- and biostratigraphic calibration of early animal evolution: Neoproterozoic-early Cambrian in southwest Mongolia. Geological Magazine 133, 445-85.

Esakova, N. V. \& Zhegallo, E. A. 1996. Stratigrafiya i fauna nizhnego kembriya Mongolii (Lower Cambrian stratigraphy and fauna of Mongolia). Sovmestnaya SovetskoMongol'skaya Paleontologicheskaya Ekspeditsiya, Trudy 46, 208 pp. (in Russian).

FANG, W., VAN DER VoO, R. \& LIANG, Q. 1990. Ordovician paleomagnetism of eastern Yunnan, China. Geophysical Research Letters 17, 953-6.

Fisher, N. I., LewIS, T. \& Embleton, B. J. J. 1987. Statistical analysis of spherical data. Cambridge: Cambridge University Press, $329 \mathrm{pp}$.

GorZheVskiY, D. I. \& ShabalovskiY, A. Ye. 1972. Some new data on deep-seated Mongol-Okhotsk fault. International Geology Review 14, 895-904.

Khasin, R. A., Borzakovskiy, Yu. A. \& Zonenshayn, L. P. (eds) 1973. Geologiya Mongol'skoy Narodnoy Respubliki: Tom II: Magmatizm, metamorfizm, tektonika (Geology of the Mongolian People's Republic: Volume II: Magmatism, metamorphism, tectonics). Moscow: Nedra Press, 752 pp. (in Russian).

Khomentovsky, V. V. \& GibsheR, A. S. 1996. The Neoproterozoic-lower Cambrian in northern Govi-Altay, western Mongolia: regional setting, lithostratigraphy and biostratigraphy. Geological Magazine 133, 371-90.

Khramov, A. N. 1982. Palaeomagnetology. Leningrad: Nedra Press, 312 pp. (in Russian).

KIRSCHVINK, J. L. 1978. The Precambrian-Cambrian boundary problem: magnetostratigraphy of the Amadeus Basin, central Australia. Geological Magazine 115, 139-50.

KIRSCHVINK, J. L. 1980. The least-squares line and plane and the analysis of paleomagnetic data. Geophysical Journal of the Royal Astronomical Society 62, 699-718.

KirschVINK, J. L., Magaritz, M., RipPeRDAN, R. L., Zhuravlev, A. Yu. \& Rozanov, A. Yu. 1991. The Precambrian/Cambrian boundary: magnetostratigraphy and carbon isotopes resolve correlation problems between Siberia, Morocco, and South China. GSA Today 1, 69-71, 87,91 .

KirschVinK, J. L. \& Rozanov, A. Yu. 1984. Magnetostratigraphy of lower Cambrian strata from the Siberian Platform: a palaeomagnetic pole and a preliminary polarity time-scale. Geological Magazine 121, 189-203.

KoROBOv, M. N. 1989. Biostratigrafiya i polimernye trilobity nizhnego kembriya Mongolii (Lower Cambrian biostratigraphy and polymeroid trilobites of Mongolia). Sovmestnaya Sovetsko-Mongol'skaya Paleontologicheskaya Ekspeditsiya, Trudy 46, 208 pp. (in Russian).

LI, Y. 1990. An apparent polar wander path from the Tarim block, China. Tectonophysics 181, 31-41.

Lindsay, J. F., Brasier, M. D., Shields, G., Khomentovsky, V. V. \& Bat-Ireedu, Y. A. 1996. Glacial facies asssociations in a Neoproterozoic back-arc setting, Zavkhan
Basin, western Mongolia. Geological Magazine 133, 391-402.

MCFAdDEN, P. L. 1990. A new fold test for palaeomagnetic studies. Geophysical Journal International 103, 163-9.

Mossakovsky, A. A., Ruzhentsev, S. V., Samygin, S. G. \& KHERASKOVA, T. N. 1992. On two types of palaeo-oceanic structures in central Asia. Doklady Akademii Nauk 323, 377-81 (in Russian).

Mossakoviky, A. A., Ruzhentsev, S. V., Samygin, S. G. \& Kheraskova, T. N. 1994. Central Asian fold belt: Geodynamic evolution and formation history. Geotectonics 27, 445-74.

PRUNER, P. 1992. Palaeomagnetism and palaeogeography of Mongolia from the Carboniferous to the Cretaceous - final report. Physics of the Earth and Planetary Interiors $\mathbf{7 0 ,}$ 169-77.

Şengör, A. M. C., Natal'in, B. A. \& Burtman, V. S. 1993. Evolution of the Altaid tectonic collage and Palaeozoic crustal growth in Eurasia. Nature 264, 299-307.

USHATINSKAYA, G. T. 1995. Drevneyshie lingulyaty (The earliest lingulates). Rossiyskaya Akademiya Nauk, Paleontologicheskiy Institut, Trudy 262, 91 pp. (in Russian).

VAN DER VOO, R. 1990. The reliability of paleomagnetic data. Tectonophysics 184, 1-9.

VAN DER VOo, R. 1993. Paleomagnetism of the Atlantic, Tethys and Iapetus Oceans. Cambridge: Cambridge University Press, $411 \mathrm{pp}$.

Voronin, Yu. I., Voronova, L. G., Grigor'EVA, N. V., Drozdova, N. A., Zhegallo, E. A., Zhuravlev, A. Yu., Ragozina, A. L., Rozanov, A. Yu., Sayutina, T. A., Sysoev, V. A. \& Fonin, V. D. 1982. The Precambrian/Cambrian boundary in the geosynclinal areas (the reference seection of Salaany-Gol, MPR). Sovmestnaya Sovetsko-Mongol'skaya Paleontologicheskaya Ekspeditsiya, Trudy 18, 152 pp. (in Russian).

Voronova, L. G., Voronin, YU. I., Drozdova, N. A., EsaKova, N. V., Zhegallo, E. A., Zhuravlev, A. Yu., Luchinina, V. A., Meshkova, N. P., Ragozina, A. L., Sayutina, T. A. \& FonIN, V. D. 1986. Organicheskie ostatki v nizhnekembriyskikh otlozheniyakh mezhdurech'ya Dzabkhana i Khunguya (Mongoliya) [Organic remains in the Lower Cambrian strata of the Zavkhan and Khungiy interfluve (Mongolia)]. Akademiya Nauk SSSR, Sibirskoe Otdelnie, Institut Geologii $i$ Geofiziki, Trudy 669, 163-8 (in Russian).

WANG, Z., VAN DER VoO, R. \& WANG, Y. 1994. Paleomagnetic results from Late Sinian/Early Cambrian rocks in Guizhou Province, South China block. In Magnetism: Rocks to Superconductors (ed. K. V. Subbarao), pp. 159-82. Geological Society of India, Memoir no. 29.

Wood, R., Zhuravlev, A. Yu. \& Chimed Tseren, A. 1993. The ecology of Lower Cambrian buildups from Zuune Arts, Mongolia: Implications for early metazoan reef evolution. Sedimentology 40, 829-58.

WU, F., VAN DER VOO, R. \& LiANG, Q. 1988/9. Reconnaissance magnetostratigraphy of the Precambrian-Cambrian boundary section at Meishucun, China. Cuademos de Geologica Iberica 12, 205-22.

Yashina, R. M., Matrenitskiy, A. T. \& Garam, D. 1979. On the relationship between Devonian and Permian orogenic magmatism in the early Caledonides of northern Mongolia. Soviet Geology and Geophysics 20, 40-6. 